\title{
Insurer's liability under concurrent causation: English law and Chinese law compared
}

\author{
Liang Zhao* ${ }^{* \dagger}$ \\ Southampton Law School, University of Southampton, Southampton, UK \\ *Author email: 1.zhao@soton.ac.uk
}

(Accepted 26 April 2021)

\begin{abstract}
This paper examines the different regimes of insurer liability under concurrent causation in English law and Chinese law. The analysis shows that neither English law nor Chinese law is satisfactory in terms of the insurer's liability in such cases. It is argued that only one proximate cause should be identified among multiple causes except in the circumstance where an excluded risk and an insured risk concurrently and independently cause a loss of the subject matter insured. Under this exception, the liability in apportionment approach might be an appropriate solution to the question of the insurer's liability under concurrent causation. This approach, however, is not suggested for concurrent causation where an uninsured risk is one of the proximate causes.
\end{abstract}

Keywords: insurer's liability; concurrent causation; sole proximate cause; liability in apportionment

\section{Introduction}

Causation is a general principle of insurance law under which an insurer will only be liable for a loss proximately caused by a risk covered by an insurance policy. The principle of proximate causation is codified in section 55(1) of the Marine Insurance Act 1906. ${ }^{1}$ In English law, the insurer is not liable for a loss concurrently caused by proximate causes if one is an insured risk and the other an excluded risk, but the insurer is liable if the loss is concurrently caused by an insured risk and an uninsured risk. In some civil laws, eg Chinese law, the insurer's liability under concurrent causation is not all or nothing, but in apportionment according to the potency of the insured risk on the loss. Insurance is an international business with a common practice, but the insurer's liability regimes under concurrent causation are not consistent in different jurisdictions, eg English law and Chinese law. The same subject matter may be insured in the Chinese market under Chinese law and then reinsured in the London market under English law. Where a loss is caused by more than one risk concurrently, the insurer may be partially liable for the loss under Chinese law, but the reinsurer may not be liable or wholly liable for the same loss under English law. If the reinsurance contract is based on back to back cover of the insurance contract, the reinsurer's liability will be subject to the insurer's liability

\footnotetext{
†This revised paper was developed during the author's visit, as Visiting Senior Research Fellow, at the Centre for Maritime Law (CML), Faculty of Law, National University of Singapore in July-August 2019. The paper was originally presented at a CML seminar on 31 July 2019. The author would like to thank CML for the funding that supported this research. The author is also grateful to the anonymous referees and to Professor James Davey of Southampton Law School for comments on previous drafts.

${ }^{1}$ Section 55 (1) states that: 'unless the policy otherwise provides, the insurer is liable for any loss proximately caused by a peril insured against, but, subject as aforesaid, he is not liable for any loss which is not proximately caused by a peril insured against'. This is the principle of proximate causation in insurance law. It is treated by the courts as also stating the law applicable to non-marine insurance.

(c) The Author(s), 2021. Published by Cambridge University Press on behalf of The Society of Legal Scholars. This is an Open Access article distributed under the terms of the Creative Commons Attribution licence (http://creativecommons.org/licenses/by/4.0/), which permits unrestricted re-use, distribution, and reproduction in any medium, provided the original work is properly cited.
} 
under the insurance contract. However, the reinsurer under English law may have different liability from the liability of the insurer under Chinese law. This predicament is caused by the different liability regimes of the insurer under concurrent causation.

From the perspective of liability, the risks in insurance can be classified under insured risk, excluded risk and uninsured risk in an insurance contract. Insured risk refers to the risk covered by the insurance contract. The insurance covers loss of the subject matter insured attributable to or caused by specified risk in the contract. Excluded risk refers to risks that the insurance does not cover. The insurance will in no case cover loss, damage or expense caused by an excluded risk. A loss or damage might be caused by a risk which is neither covered nor excluded by an insurance contract. This kind of risk could be called an uninsured risk. Uninsured risk is contractually irrelevant to a loss although it might be a cause to the loss in fact. Those kinds of risks may proximately cause a loss successively or simultaneously. They are called the concurrent causes. It is also called combination of causes: ${ }^{2}$ the combination of more than one cause which together made a loss inevitable. Neither would have caused the loss without the other. ${ }^{3}$ At common law, the concurrency was described as being two causes jointly and simultaneously leading to the loss. ${ }^{4}$ The concurrent causes were referred to two causes that were equal or nearly equal in their efficiency in bringing about the damage. ${ }^{5}$ Concurrent causation in this paper refers to a causative link between a loss and more than one simultaneous risk to the subject matter insured. ${ }^{6}$

Where the risks successively caused a loss, the English courts identify one of the risks as the proximate cause which is the dominant, effective or operative cause of the loss. ${ }^{7}$ Where the risks simultaneously caused a loss, the English courts also identify one proximate cause, ${ }^{8}$ but open the question of the insurer's liability with more than one proximate cause. ${ }^{9}$ It has been established in English common law that the insurer is not liable for a loss concurrently caused by more than one proximate cause, one of which is an insured risk and the other an excluded risk. ${ }^{10}$ The insurer is liable for a loss under concurrent causation where one proximate cause is an insured risk and the other is an uninsured risk. ${ }^{11}$ Those established English common law approaches also apply to a circumstance where the number of separate events that combine to bring about loss is multiplied many times over. In Financial Conduct Authority $v$ Arch Insurance (UK) Ltd and Others, ${ }^{12}$ one of the questions was whether business interruption losses consequent on public health measures taken in response to Covid-19 were, in law, caused by cases of the disease that occurred within the specified radius of the insured premises. The Supreme Court agreed with the court below that it is realistic to analyse this situation as one in which 'all the cases were equal causes of the imposition of national measures'. ${ }^{13}$

However, English law is not the universal approach in worldwide insurance law. The issue of causation in insurance is a major divide between common law countries and countries of the continental legal culture. Even in continental law jurisdictions, there is no uniformity on the causation issue in insurance law. ${ }^{14}$ For insurer's liability under concurrent causation, the common law approach may

\footnotetext{
${ }^{2} \mathrm{~J}$ Gilman et al Arnould: Law of Marine Insurance and Average (Sweet \& Maxwell, 19th edn, 2018) paras 22-28.

${ }^{3}$ Financial Conduct Authority v Arch Insurance (UK) Ltd and Others [2021] UKSC 1, at [175].

${ }^{4}$ Board of Trade $v$ Hain Steamship Co Ltd [1929] All ER Rep 26, at 30.

${ }^{5}$ Wayne Tank and Pump Co Ltd v Employers Liability Assurance Corp Ltd [1973] 3 All ER 825 at 830.

${ }^{6}$ For more detailed discussion of the definition of 'concurrent causes' see M Song Causation in Insurance Contract Law (London: Informa, 2014) pp 59-65.

${ }^{7}$ Reischer v Borwick [1894] 2 QB 548; Leyland Shipping Co v Norwich Union Fire Insurance Society [1918] AC 350.

${ }^{8} J J$ Lloyd Instruments Ltd $v$ Northern Star Insurance Co Ltd (The Miss Jay Jay) [1986] EWCA Civ 10; Wayne Tank and Pump Co Ltd v Employers Liability Assurance Corp Ltd, above n 5.

${ }^{9}$ Global Process Systems Inc v Syarikat Takaful Malaysia Bhd (The Cendor MOPU) [2011] UKSC 5, [2011] 1 All ER 869 at [88] (Lord Mance).

${ }^{10}$ Wayne Tank and Pump Co Ltd v Employers Liability Assurance Corp Ltd, above n 5.

${ }^{11} \mathrm{JJ}$ Lloyd Instruments Ltd $v$ Northern Star Insurance Co Ltd (The Miss Jay Jay) [1986] EWCA Civ 10.

${ }^{12}$ [2021] UKSC 1.

${ }^{13}$ Ibid, at [176].

${ }^{14} \mathrm{D}$ Thomas Marine Insurance: The Law in Transition (London: Informa, 2006) para 8.29.
} 
result in rather harsh results for the insured. Belgium, by contrast, adopts the 'theory of the equivalent causes'. This theory takes into account all relevant circumstances that may have contributed and without which the loss or damage could not have occurred. ${ }^{15}$ The Belgian principle of equivalent conditions allows the apportionment of liability. ${ }^{16}$ It is argued that the apportionment of liability is more equitable for the insured and it surely allows greater flexibility. ${ }^{17}$ Because of the great difference in approach between English law and civil laws, it is meaningful to have a comparative study of different laws. In recent years, Chinese courts have adopted a similar theory and have applied an apportionable liability approach in judicial practice. The insurer's liability under concurrent causation in Chinese law is determined according to the potency of the insured risks on the loss of the subject matter insured. The Chinese courts take into account all concurrent causes including insured risks, uninsured risks and excluded risks which contributed to the loss and allocate a certain proportion to a given cause for determining the insurer's liability in apportionment. The recent development of Chinese law and judicial practice represent the typical apportionment approach and comprehensively demonstrate both the rationality and limitations of the apportionment approach. By the comparison of English law and Chinese law, alternative and reasonable approaches have been worked out.

\section{Insured risk and excluded risk}

\section{(a) Priority of exclusion in English law}

The Marine Insurance Act 1906 defines causation in both positive and negative ways. It provides that 'unless the policy otherwise provides, the insurer is liable for any loss proximately caused by a peril insured against, but, subject as aforesaid, he is not liable for any loss which is not proximately caused by a peril insured against'. ${ }^{18}$ In non-marine insurance that has always been the rule at common law. ${ }^{19}$ The Marine Insurance Act 1906 does not contain provisions regarding concurrent causation. The question of insurer's liability under concurrent causation was left to common law. It has been generally accepted by common law that an insurer is not liable for a loss under concurrent causes, one excluded and the other insured. The commonly accepted authority is Wayne Tank and Pump Co Ltd v Employers Liability Assurance Corp Ltd (Wayne Tank), ${ }^{20}$ which was confirmed by the Supreme Court in Atlasnavios-Navegacao Lda $v$ Navigators Insurance Co Ltd (The B Atlantic) ${ }^{21}$ and Financial Conduct Authority $v$ Arch Insurance (UK) Ltd and Others. ${ }^{22}$ Although both the excluded risk and the insured risk are proximate causes, the excluded risk prevails over the insured risk. The main reason for this conclusion is that an insurer is 'warranted free' from liability of indemnity for a loss which is not apportionable. Lord Sumner in Board of Trade v Hain Steamship Co Ltd explained this in the words of Lloyd's underwriters:

This loss, which is a collision loss, is one loss, the product of two causes, joint and simultaneous, namely, the eccentric courses steered by the two vessels. The whole voyage of the Roanoke, and therefore this part of it, was a warlike operation, and from losses so caused this policy is warranted

\footnotetext{
${ }^{15}$ Similarly, in Norwegian Cargo Clauses: Conditions relating to Insurance for the Carriage of Goods of 1995 Version 2004, $\$ 20$ Combination of risks, it is provided that 'If the loss has been caused by a combination of several different risks, and one or more of these risks are not covered by this insurance, the loss shall be apportioned proportionally among the various risks according to the potency which each of them must be assumed to have had on the occurrence and extent of the loss, and the Insurer shall only be liable for that part of the loss which is attributable to the risks covered by this insurance'.

${ }^{16}$ Thomas, above $\mathrm{n} 14$, paras 8.32 and 8.33 .

${ }^{17}$ Ibid, para 8.33 .

${ }^{18}$ Marine Insurance Act 1906, s 55 (1).

${ }^{19}$ Wayne Tank, above $\mathrm{n} 5$, at 834.

${ }^{20}$ Wayne Tank, above $\mathrm{n} 5$. This case is reinforced by the decision in Midland Mainline v Eagle Star Insurance Co Ltd [2004] EWCA Civ 1042. See also J Lowry and P Rawlings 'Proximate causation in insurance law' (2005) 68 MLR 310.

${ }^{21}$ [2018] UKSC 26, [2019] AC 136.

${ }^{22}$ [2021] UKSC 1 . However, the facts of this case are distinguishable in respect of concurrent causation from the facts of Wayne Tank and The Miss Jay Jay.
} 
free. Neither in law nor in fact is this collision and its resulting damage apportionable - hence no part of it can fall on this policy. ${ }^{23}$

However, it is submitted that the phrase 'warranted free' and the non-apportionable nature of a loss do not automatically release the insurer from liability.

First, it must be clarified that the said 'warranted free' is not a real warranty in insurance law. The warranty clause is commonly used in hull insurance. In Board of Trade v Hain Steamship Co Ltd, the exclusion clause provided: 'Warranted free ... from all consequences of hostilities or warlike operations, whether before or after declaration of war'. ${ }^{24}$ Lord Sumner opined that where there is one loss which is the product of two causes joint and simultaneous - and loss due to one of the causes is exempt, being 'warranted free' - then the underwriters are not liable. ${ }^{25}$ It must be noted that 'warranted free' is not a warranty but an exclusion in insurance contract law. A warranty in insurance law means 'a promissory warranty, that is to say, a warranty by which the assured undertakes that some particular thing shall or shall not be done, or that some condition shall be fulfilled, or whereby he affirms or negatives the existence of a particular state of facts'. ${ }^{26}$ Breach of a warranty in an insurance contract results in the discharge of the insurer's liability unless such a breach could be and has actually been remedied. ${ }^{27}$ Obviously, 'warranted free' is not such a warranty upon breach under which an insurer can discharge from liability. ${ }^{28}$ In Wayne Tank, the insurer was discharged from liability not because of breach of a warranty, but because of the construction of the insurance contracts, which stated that 'the [insurance] Company will indemnify the Insured against all sums $\ldots$ as a result of ... [indemnity clause]'. An exception in the policy stated that ' $t$ ] he [insurance] Company will not indemnify the Insured in respect of liability consequent upon ... [the exclusion clause]'. In this circumstance, there is no reason to conclude that the exclusion clause or indemnity clause prevails unless the clauses state the relation between the excluded risks and insured risks, eg 'the Company will indemnify the Insured against all sums ... as a result of ..., except as excluded consequent upon ....29

Second, it is doubtful whether 'warranted free' can prevail over the undertaking of indemnity in an insurance contract. Lord Denning MR in Wayne Tank construed that when it is agreed to be 'warranted free', 'the only way of giving effect to it is by exempting them altogether. ${ }^{30}$ This is because, 'if the underwriters were held liable for loss, they would not be free of it. The loss is not apportionable. Hence no part of it can fall on the policy.' ${ }^{31}$ It is true that a loss caused by concurrent causes is not apportionable, but the question is why the underwriter should be free from liability when it also undertakes to indemnify the insured for the loss caused by an insured risk. On the one hand, the insurer is warranted free from liability for a loss caused by an excluded risk. On the other hand, the insurer undertakes to indemnify the insured against the loss caused by an insured risk. There is no substantial difference between 'undertake' and 'warranty' in terms of the insurer's liability. ${ }^{32}$ Both phrases mean the promise of the parties to each other. When an insurer promises to indemnify an insured of a loss caused by one risk, and meanwhile the insured promises to free the insurer from

\footnotetext{
${ }^{23}$ Board of Trade $v$ Hain Steamship Co Ltd, above n 4, at 30-31.

${ }^{24}$ It is clause 19 of a charter party in dispute. The charterer agreed to undertake the risks excluded from an ordinary insurance policy of marine insurance by this clause.

${ }^{25}$ Board of Trade $v$ Hain Steamship Co Ltd, above $\mathrm{n} 4$, at 31.

${ }^{26}$ Marine Insurance Act 1906, s 33(1).

${ }^{27}$ Insurance Act 2015, s 10.

${ }^{28}$ It is believed that Wayne Tank is authority for the proposition that no distinction exists for the concurrent causation between clauses commencing with the words 'warranted free' and other types of exception clauses. See J Gilman et al Arnould: Law of Marine Insurance and Average (Sweet \& Maxwell, 16th edn, 1981) para 777.

${ }^{29}$ The conjunction word is italicised to emphasise the relation between the cover clause and the exclusion clause.

${ }^{30}$ Wayne Tank, above n 5 , at 830 .

${ }^{31}$ Ibid.

${ }^{32}$ In Wayne Tank, all Lords unanimously construed that the phrase 'warranted free' in a marine insurance policy has the same effect as the words of a non-marine policy: 'The Company will not indemnify...'.
} 
its liability for the same loss caused by the other risk, it is difficult to infer whose promise prevails. Like the concurrent existence of the insured risk and excluded risk, the liability and the exemption exist concurrently. There is no reason to imply that any one risk is preceded by the other risk. It can be construed that the insurer is warranted free from liability although it should be liable concurrently. However, it can also be construed conversely that the insurer undertakes to indemnify the loss although it could be free from the liability for the loss. Therefore, it is equally logical to interpret that the underwriters should be liable for the loss because the loss is not apportionable, and hence no part of it can fall off the policy. ${ }^{33}$

Furthermore, the Lords in Wayne Tank prioritised the exclusion clause by classification of the covered clause and the exclusion clause. The classification, however, was not logically reasoned out or supported by any authority. Lord Denning MR explained the priority of the exclusion as emanating from the nature of the covered clause and the exclusion clause:

The result is that, although this accident comes within the general words at the opening of the policy, nevertheless seeing that there is a particular exception, the exception takes priority over the general words. General words always have to give way to particular provisions. ... Their exemption is not taken away by the fact that there was another cause equally efficient also operating to cause the loss. ${ }^{34}$

In a contract, the particular words may take priority over the general words. However, it is not known why the cover clause should be general words whereas the exclusion clause could be particular words. There are no criteria for determining the general words and particular words in Wayne Tank. In fact, both the cover clause and the exclusion clause are general words. For example, the policies in Wayne Tank provided that 'the (insurance) Company will indemnify the Insured against all sums ... consequent upon ...' and 'the Company will not indemnify the Insured in respect of ... consequent upon .... There are no words indicating which clause is general or particular in the policy. They are parallel provisions and equally important in the insurance contract. It is therefore argued that, unless otherwise agreed in the policy, no clause should give way to the other. If this argument is acceptable, it might be submitted, as Lord Denning MR did, '[T]heir cover is not taken away by the fact that there was another cause (the excluded risk) equally efficient also operating to cause the loss' ${ }^{35}$ In other words, unless an insurance contract provides otherwise, ${ }^{36}$ there should be no general rule that the excluded risk prevails over the insured risk so as to exclude the insurer's liability under concurrent causation. ${ }^{37}$ If these arguments are accepted, there should be different approaches for this matter. A suggested way is to hold that since either of the perils may be treated as the cause of the loss, the exclusion of one of them should not logically interfere with the operation of the other, upon which, therefore, a valid claim can be based. ${ }^{38}$ However, this is a similar way to give priority to exclusion without reasonable rationale. There is another solution, which could be found in the experiences of Chinese law.

\footnotetext{
${ }^{33}$ Words are italicised to show the difference from the originally quoted words.

${ }^{34}$ Wayne Tank, above $\mathrm{n} 5$, at 830 .

${ }^{35}$ Words are italicised and added in brackets to show the difference from the originally quoted words.

${ }^{36} \mathrm{Eg}$ Institute Cargo Clauses (A) 2009, clause 1: This insurance covers all risks of loss of or damage to the subject matter insured except as excluded by the provisions of Clauses 4, 5, 6 and 7 below. It shows that the excluded risks in clauses 4 to 7 prevail over the insured risks even if all risks.

${ }^{37}$ The reasoning in Wayne Tank has been rejected in Canada in Derksen $v 539938$ Ontario Ltd [2001] SCC 72 in which the Supreme Court held that Wayne Tank did not apply in the absence of clear wording and that the insurers were liable because exclusion clauses in insurance policies are to be interpreted narrowly and generally in favour of the insured in case of an ambiguity in the wording. But the Court of Appeal of New Zealand in MI Insurance Ltd v Legg [2017] NZCA 321 held that this was a case where both the insuring clause and the exclusion were engaged by interdependent causes and that the Wayne Tank rule should apply.

${ }^{38}$ Gilman et al, above n 28, para 776.
} 


\section{(b) The apportionable liability approach in Chinese law}

The statutes governing insurance contracts in China are the Insurance Law of the People's Republic of China 1995, as amended in 2002, 2009, 2014 and 2015 (Chinese Insurance Law) and the Maritime Code of the People's Republic of China 1992 (Chinese Maritime Code). The Chinese Insurance Law is a general law for contracts of both life insurance and non-life insurance. ${ }^{39}$ The Chinese Maritime Code is a special law for contracts of marine insurance. ${ }^{40}$ The concept of causation is regulated by both the Chinese Insurance Law and the Chinese Maritime Code. Under the Chinese Insurance Law, the insurer bears an obligation to pay the policy holder indemnities against property loss 'caused as a result of the occurrence of a contingent event as agreed upon in the contract, or pay the insurance benefits when the insured dies, is injured or disabled, suffers illness or reaches the age limit, time limit or any other condition agreed upon in the contract. ${ }^{41}$ Under the Chinese Maritime Code, the insurer undertakes, as agreed, to indemnify the loss of the subject matter insured and the liability of the insured 'caused by' perils covered by the insurance. ${ }^{42}$ From the concept of causation in Chinese law, it can be seen that the insurer's liability is for a loss or damage caused by the perils covered by the insurance contract. In other words, the insurer will not be liable if a loss or damage is caused by uninsured perils or excluded perils in the insurance contract. The cause for insurance liability in Chinese law means the proximate cause, although Chinese statutes do not expressly use the phrase 'proximate cause'. ${ }^{43}$

In Chinese judicial practice, the concept of proximate cause has been applied in insurance disputes. ${ }^{44}$ If more than one cause is the proximate cause, they will be regarded as concurrent proximate causes (concurrent causes). In China, the main source of law is the statutes. However, the superior courts, including the Supreme People's Court (SPC), formulate judicial interpretations on the specific application of law for trials in Chinese courts. The judicial interpretations, in particular the interpretations from the SPC, are legally effective for the implementation of statutes. ${ }^{45}$ Lower level courts must apply the judicial interpretations from superior courts. Chinese judicial interpretations apply as quasilegislation in Chinese judicial practice. ${ }^{46}$

On this basis, Chinese provincial level courts started to 'interpret' the insurer's liability under concurrent causation. ${ }^{47}$ In the judicial interpretations of the High People's Courts in Shandong and Guangdong Provinces of China, where there are multiple proximate causes, Chinese courts will examine whether one of the proximate causes of loss is covered by the insurance. If it is covered, the insurer shall be liable for the loss even if other proximate causes are excluded or uncovered. ${ }^{48}$ The insurer in this circumstance shall be liable for loss or damage according to the causative potency of the insured

\footnotetext{
${ }^{39}$ The Chinese Insurance Law also regulates the matters of insurance company, insurance business, insurance intermediates and supervision and administration over the insurance industry in China.

${ }^{40}$ It is Chapter XII Contract of Marine Insurance in the Chinese Maritime Code.

${ }^{41}$ Chinese Insurance Law, art 2.

${ }^{42}$ The covered perils mean any maritime perils agreed upon between the insurer and the insured, including perils occurring in inland rivers or on land which is related to a maritime adventure: Chinese Maritime Code, art 216.

${ }^{43}$ It is understood that the phrases 'caused as a result of and 'caused by' imply the principle of causation in Chinese law. See B Chu 'Current issues and developments in Chinese insurance law' in J Hjalmarsson and D Huang (eds) Insurance Law in China (London: Informa, 2015) p 100. Cf Marine Insurance Act 1906, s 55(1).

${ }^{44}$ Fuqing Hengyao Real Estate Development Co Ltd v China Life Property \& Casualty Insurance Co Ltd Fuzhou Central Branch (2014) MSZ No 1007 (SPC, Retrial).

${ }^{45}$ Provisions of the Supreme People's Court on the Work Concerning Judicial Interpretation 2007, arts 3 and 4.

${ }^{46}$ Chinese judicial interpretations may not be the real interpretation of statutes. They might be new rules created by the courts if there are no relevant provisions in statutes.

${ }^{47}$ In fact, there is no statutory rules regarding the insurer's liability under concurrent causation in either the Chinese Insurance Law or the Chinese Maritime Code. So, the Chinese courts actually created new rules instead of an interpretation of statutory rules.

${ }^{48}$ Opinions of the Shandong High People's Court on Several Issues about the Trial of Cases Concerning Insurance Contract Disputes (Trial) 2011, art 14.
} 
peril in all proximate causes. ${ }^{49}$ This apportionable liability approach has been applied by courts in Shandong and Guangdong Provinces, but has not been expressly accepted by the High People's Courts in other provinces of China. ${ }^{50}$ Judicial interpretations from High People's Courts apply only in the jurisdictions of the High People's Courts. Only the juridical interpretations from the SPC apply nationwide to all Chinese courts.

The SPC promulgated the Interpretations of the Supreme People's Court on Several Issues Concerning the Application of the Insurance Law of the People's Republic of China (III) (Insurance Law Interpretation III) in $2015 .^{51}$ Article 25 of the Insurance Law Interpretation III provides that, where it is difficult to determine whether the loss suffered by the insured is caused by an insured event, an uninsured event or an exempted event, the court may uphold the claim of a party concerned for the payment of insurance benefits by the insurer concerned according to the corresponding potency. This is called the 'principle of proportional causation'. ${ }^{52}$ Accordingly, the insurers' liability in concurrent causation could be apportioned. The purpose of the apportionable liability approach in the Insurance Law Interpretation III is to avoid a harsh result to the insured if an excluded risk as one of the proximate causes exempts the insurer's whole liability when another proximate cause is an insured risk. ${ }^{53}$

It has been explained that the Insurance Law Interpretation III is for life insurance. ${ }^{54}$ The apportionable liability approach in the Interpretation III was thus designed for life insurance rather than non-life insurance. It is reasonable to accept the apportionable liability approach is for the protection of interests of the insured as consumers in life insurance. However, the Insurance Law Interpretation III does not indicate that the apportionable liability approach should not apply to non-life insurance contracts. At least, the Insurance Law Interpretation III itself does not exclude the application of the apportionable liability approach to the non-life insurance. Although there are no reported cases from Chinese courts in which the apportionable liability approach in the Insurance Law Interpretation III has been applied to non-life insurance, Chinese courts have applied the apportionable liability approach to non-life insurance disputes for the determination of insurers' liability under concurrent causation, in particular in property insurance disputes. For liability insurance, the apportionable liability approach is also applied between the insurer and the insured, although the injured third parties may claim compensation against the insurer if a loss is caused by a covered cause even though an excluded or uninsured cause may have combined together to produce the loss. ${ }^{55}$ It is believed that Chinese courts have accepted the apportionable liability approach for both life insurance and non-life insurance. The apportionable liability approach has become a commonly accepted principle applied in judicial practice of Chinese courts in insurance concurrent causation disputes.

It should be noted that Mainland China is a civil law jurisdiction and judgments from Chinese courts, including the SPC, are not precedents or binding law. However, this does not mean that Chinese judgments, in particular judgments from the SPC, are not important. In fact, judgments have been playing a more and more important role in Chinese judicial practice. Since 2010, the SPC, by formulating its 'Provisions of the Supreme People's Court on Case Guidance Work', has begun to issue guiding cases, to set out unified standards for the application of laws and to ensure

\footnotetext{
${ }^{49}$ Guiding Opinions of the Guangdong High People's Court on Several Issues about the Trial of Cases Concerning Insurance Contract Disputes 2011, art 17.

${ }^{50}$ Eg in Guiding Opinions of the Beijing High People's Court on Several Issues about the Trial of Cases Concerning Insurance Contract Disputes (Trial) 2005; Guiding Opinions of the Zhejiang High People's Court on Several Issues about the Trial of Cases Concerning Insurance Contract Disputes 2009; and Minutes of Discussion of the Jiangsu High People's Court on Several Issues about the Trial of Cases Concerning Insurance Contract Disputes 2011.

${ }^{51}$ Insurance Law Interpretation I and II have no provisions relating to concurrent causation.

${ }^{52} \mathrm{Chu}$, above n $43, \mathrm{p} 101$.

${ }^{53} \mathrm{~W}$ Du et al, Explanation and Application of the SPC's Insurance Law Judicial Interpretation III (Beijing: People's Court Press, 2015) pp 584-585.

${ }^{54}$ Press conference on Insurance Law Interpretation III held by the SPC on 26 November 2015: http://www.court.gov.cn/ zixun-xiangqing-16101.html (in Chinese) (last accessed 25 May 2021).

${ }^{55}$ Chinese Insurance Law, art 65; cf Third Parties (Rights against Insurers) Act 2010.
} 
equal justice under law. The SPC publishes its 'guiding cases' and Chinese courts at all levels must take them as a reference in the trials of similar cases. ${ }^{56}$ In 2020, the SPC formulated 'Guiding Opinions of the Supreme People's Court on Unifying Application of Laws and Strengthening Similar Case Retrieval (Trial). ${ }^{57}$ According to these Guiding Opinions, Chinese courts should search for similar cases in official databases of judgments when necessary. ${ }^{58}$ The scope of similar case retrieval mainly include the SPC's guiding cases, typical cases and cases with effective judgments, reference cases and cases with effective judgments delivered by the high court of the provinces and cases with effective judgments as adjudicated by the court and courts at a higher level. ${ }^{59}$ If a similar case found is a guiding case, it shall be referred to by the court when it renders its judgment. Any other similar case, including judgments from the SPC, shall be taken by the court as reference for rendering judgment. ${ }^{60}$ With the development of the guiding case system and referring cases system, Chinese judgments have been impliedly accepted as 'binding law' in China. Therefore, Chinese judicial practice, in particular the judgments of the SPC, are worthy of study.

\section{(c) Apportionable liability approach in Chinese judicial practice}

Where a loss is concurrently caused by both an insured risk and an uninsured risk, the insurer is not liable under English law. It may be queried, however, why the excepted cause prevails over the insured cause. ${ }^{61}$ In this circumstance, the SPC has applied the apportionable liability approach for determining the insurer's liability. In Wenzhou Hongda Marine Shipping Co Ltd v Sunshine Property \& Casualty Insurance Co Ltd Wenzhou Central Branch (The Hong Da 158), ${ }^{62}$ the vessel was insured by the insurer against all risks in coastal and inland waters in China. Clause 1 of the insurance policy provided that the insurer was liable for the total loss of the vessel as a result of collision or contact of the vessel. Clause 3 provided that the insurer was not liable for any loss, liability or cost caused by unseaworthiness including the technical status, manning and loading of the vessel. The vessel was overloaded with goods and commenced its voyage with one qualified master and five unqualified crew. When the vessel sailed under a bridge, the master did not know the hydrological status of the water and chose the wrong arch. Consequently, the vessel collided with the anti-collision pier and sank soon after. After investigation, the local maritime authority reported that the direct reason for the accident was the improper operation of the master sailing under the bridge and the indirect reason was the overloading of the goods.

It could be concluded that the proximate causes of the loss of the vessel were the collision due to the master's fault in navigation and the unseaworthiness of the vessel due to the overloading of the goods. ${ }^{63}$ According to the policy in this case, the collision due to the master's fault in navigation is a covered risk and the unseaworthiness of the vessel is an excluded risk. Different levels of Chinese courts have taken different views on the insurer's liability under concurrent causation. The difference is mainly based on the finding of the proximate cause and the construction of the policy. In the first

\footnotetext{
${ }^{56}$ Provisions of the Supreme People's Court on Case Guidance Work, art 7.

${ }^{57}$ The Guiding Opinions were implemented on a trial basis on 31 July 2020.

${ }^{58}$ It is necessary in the following circumstances: (1) The case is proposed to be submitted to the conference of professional (presiding) judges or the judicial committee for discussion; (2) There are no specific rules for judgment or the unified rules for judgment have not yet formed for the case; (3) Similar case retrieval is required by the court president or the chief judge of the tribunal according to the trial supervision and management authority; and (4) Any other circumstance where similar case retrieval is required. See Guiding Opinions of the Supreme People's Court on Unifying Application of Laws and Strengthening Similar Case Retrieval (Trial), art 2.

${ }^{59}$ Guiding Opinions of the Supreme People's Court on Unifying Application of Laws and Strengthening Similar Case Retrieval (Trial), art 4.

${ }^{60}$ Ibid, art 9.

${ }^{61} \mathrm{Z}$ Jing Chinese Insurance Contracts: Law and Practice (London: Informa, 2014) p 402.

${ }^{62}$ (2016) Z72MC 1585 (Ningbo Maritime Court, First Instance); (2017) ZMZ 89 (Zhejiang High People's Court, Second Instance); (2017) ZGFMS 4824 (SPC, Retrial).

${ }^{63}$ Warranty of seaworthiness was not an issue in dispute in this case.
} 
trial of The Hong Da 158, the insurer contended that the cause of unseaworthiness was excluded by the insurance. The Ningbo Maritime Court accepted this contention and held that the insurer was not liable for the loss of the vessel. ${ }^{64}$ However, the appellate court considered the report from the local maritime authority and held that both the collision and the unseaworthiness were the proximate causes for the loss of the vessel. ${ }^{65}$ The SPC upheld the finding of concurrent causes by the appellate court. ${ }^{66}$ The trial court did not discuss whether the excluded peril prevails over the insured peril. In fact, the trial court did not consider the cause of collision although the loss caused by collision due to the master's fault was covered by the insurance. It is not known whether the trial court was of the view that the excluded peril prevails over the insured peril, but the consequence of the insurer's liability is the same as that of English common law. ${ }^{67}$

More importantly, the trial court did not construe the relation between the insured peril and the excluded peril in the insurance contract, perhaps because it did not consider the insured peril to be one of the proximate causes. The appellate court, by finding the concurrent causes, discussed the insurer's liability under concurrent causation from the perspective of the relation between the insured peril and the excluded peril. The appellate court pointed out that there was no agreement in the insurance policy for the insurer's liability in the concurrent causation situation. Therefore, the insurer had to prove how the excluded risk could prevail over the covered risk if it wanted to reply on the defence of exclusion. ${ }^{68}$ Obviously, in the view of the appellate court, unless otherwise agreed by parties, the excluded peril does not inevitably prevail over the insured peril when they are concurrent causes to the same loss. Therefore, in the absence of express priority in insurance contracts, both the excluded peril and the insured peril should be considered for determining the insurer's liability under concurrent causation. This provides a logical basis for determining the insurer's liability according to the degree of potency of the causes, namely the effect of the causes to the loss.

Since both the insured peril and the excluded peril are decisive to the insurer's liability, it is important to find the degree of potency of each cause to the loss. The appellate court in The Hong $\mathrm{Da} 158$ determined that the insurer should be liable for $70 \%$ of the loss of the vessel. ${ }^{69}$ However, it did not explain how it determined the percentage of the loss as the insurer's liability. The SPC upheld the decision of the appellate court and explained the reason, by saying that, in general, the extent of exclusion should be determined according to the degree of causation between the excluded risk and the loss thereby caused, namely the unseaworthiness and the collision of the vessel. According to the report from the local maritime authority, the unseaworthiness was the indirect reason and the master's fault which caused the collision was the direct reason. In the view of the SPC, the main and decisive reason for the accident was not the unseaworthiness but the master's fault. In this circumstance, the insurer could be partially exempted from liability for the unseaworthiness reason. Therefore, it was reasonable for the appellate court to hold $70 \%$ of the loss as the insurer's liability. ${ }^{70}$

This is how the Chinese courts have determined the apportionment of liability of the insurer under concurrent causes when one is excluded and the other is insured. It is appropriate to interpret the insurance contract to find the intention of the parties regarding the insurer's liability when a loss or damage was concurrently caused by an insured risk and an excluded risk as concurrent proximate causes. Ascertaining the parties' intentions is a complicated issue in law. According to the Chinese Contract Law 1999, if any disputes arise between the parties over the understanding of any clause in a contract, the true meaning thereof shall be determined according to the words and sentences used in the contract, the relevant provisions in the contract, the purpose of the contract, the

\footnotetext{
${ }^{64}$ The Hong Da 158 (2016) Z72MC 1585 (Ningbo Maritime Court, First Instance).

${ }^{65}$ The Hong Da 158 (2017) ZMZ 89 (Zhejiang High People's Court, Second Instance).

${ }^{66}$ The Hong Da 158 (2017) ZGFMS 4824 (SPC, Retrial).

${ }^{67}$ Wayne Tank, above n 5.

${ }^{68}$ The Hong $\mathrm{Da} 158$, above n 65.

${ }^{69}$ Ibid.

${ }^{70}$ The Hong $\mathrm{Da} 158$, above n 66.
} 
transaction practices and the principle of good faith. ${ }^{71}$ If there is a dispute over the understanding of the standard clauses, eg the standard insurance clauses, and there are two or more kinds of interpretation, an interpretation unfavourable to the party supplying the standard terms shall prevail. ${ }^{72}$ Therefore, Chinese courts should first identify the real intention of the parties by interpreting the cover clause and the exclusion clause and then determine liability in favour of the insured if standard clauses are used in the insurance contract.

Where, as in The Hong $\mathrm{Da}$ 158, there is no express clause indicating the intention of the parties, it is difficult to find any of their implied intentions because there is no liability regime of the insurer under concurrent causation emanating from the purpose of the insurance contract, the insurance practices or the principle of good faith. The insurer provides the standard clauses of the insurance contract. Chinese courts, however, are unable to interpret the insurance contract against the insurer because it is not a dispute about interpretation of clauses as there re no clauses in contract in terms of the insurer's liability under concurrent causation. In this circumstance, the Chinese courts created the apportionable liability approach, as in The Hong $\mathrm{Da} 158 .{ }^{73}$ Although this approach has no clear statutory basis, it seems reasonable as a means of balancing the benefits of the insurer and the insured in a concurrent causation dispute. ${ }^{74}$ It is understood that English courts intend to protect the insurer's benefit and expectation more than those of the assured because of the Wayne Tank rule in concurrent causation situations. ${ }^{75}$ Where no contractual intention could be found by construction of the insurance contract, it is better to balance the interests of parties to the insurance contract, rather than protect the interests of any one of the parties. For application of this newly proposed principle of balance of interests in insurance law, ${ }^{76}$ courts should exercise discretion to decide the insurer's liability in apportionment according to the causative potency of the insured risk to the loss concurrently caused by the excluded risk.

\section{Insured risk and uninsured risk}

\section{(a) Whole liability at English common law}

Where there are two proximate causes, one that is covered and one that is not covered but is also not excluded, the insurers are liable. This common law rule was confirmed by JJ Lloyd Instruments Ltd $v$ Northern Star Insurance Co Ltd (The Miss Jay Jay). ${ }^{77}$ Even before the authority of The Miss Jay Jay, the principle was stated in Halsbury's Laws of England: 'It seems that there may be more than one proximate (in the sense of effective or direct) cause of a loss. If one of these causes is insured against under the policy and none of the others is expressly excluded from the policy, the assured will be entitled to recover. ${ }^{78}$ In The Miss Jay Jay, the marine policy provided that no claim shall be allowed in respect of any loss or expenditure incurred solely in the event of damage resulting from faulty design. Evidence proved that but for a combination of unseaworthiness due to design defects and an adverse sea, the loss would not have been sustained. Therefore, both the sea conditions and the unseaworthiness due to the design defects of the vessel were the proximate causes of the damage to the vessel. Since

\footnotetext{
${ }^{71}$ Chinese Contract Law, art 125, para 1.

${ }^{72}$ Ibid, art 41.

${ }^{73}$ Unlike common law judges, Chinese judges - including judges from the SPC - have no authority to create judge-made law.

${ }^{74}$ In contrast, the Supreme Court of Canada in Derksen $v 539938$ Ontario Ltd [2001] SCC 72 held that Wayne Tank did not apply in the absence of clear wording and that the insurers were liable because exclusion clauses in insurance policies are to be interpreted narrowly and generally in favour of the insured in case of ambiguity in the wording (contra proferentem).

${ }^{75}$ Song, above n 6, p 79.

${ }^{76}$ The balance of interests doctrine is also a legal theory in US law. It means that conflicts of jurisdiction and interests between governmental organisations are decided based on the balance of interests between them. See R Thakur 'A balance of interests' in A Cooper et al (eds) The Oxford Handbook of Modern Diplomacy (Oxford: Oxford University Press, 2013) ch 3. This doctrine, however, has no relation to the proposed 'balance of interests principle' for concurrent causation in insurance law.

${ }^{77}$ [1987] 1 Lloyd's Rep 32.

${ }^{78}$ Halsbury's Laws (4th edn, 2006) vol 25, para 181.
} 
the marine policy in dispute contained no relevant exception relating to loss caused by unseaworthiness of the vessel, the approach taken in Wayne Tank would not apply to the situation in this case. Therefore, the Court of Appeal applied the principle in Halsbury's Laws of England to this case. The Miss Jay Jay became the authority for the issue of insurers' liability for damage caused by concurrent causes involving one insured risk and one uninsured risk. The principle in Halsbury's Laws of England, as cited in The Miss Jay Jay, is based on the construction of the policy. Although there was another proximate cause to the loss, such a cause was not covered or excluded. It was not the intention of the parties to the policy that the loss caused by the uninsured peril should be covered by the insurer or excluded from the policy. Therefore, the uninsured peril was a proximate cause as a matter of fact; it was not an issue relating to the insurer's liability as a matter of law.

\section{(b) Apportionable liability approach in Chinese judicial practice}

By contrast, the Chinese courts have applied the apportionable liability approach to insurer's liability where a loss is concurrently caused by an insured peril and an uninsured peril which is not excluded by insurance. In Chinese judicial practice, the uninsured peril as one of the concurrent causes could exclude the insurer's liability in apportionment if the insurer should be liable for the loss caused by the insured peril. This situation can be seen in Qu Rongmo v China Continent Property \& Casualty Insurance Co Ltd Weihai Branch \& Shidao Branch (The Lu Rong Yu 1813 \& The Lu Rong Yu 1814). ${ }^{79}$ In this case, the claimant shipowner had two fishing vessels, $M / V$ Lu Rong $Y u 1813$ and M/V Lu Rong Yu 1814, insured by the defendant insurer. Clause 2 of the insurance policy provided that the insurance covered loss of or damage to the vessels caused by natural disasters and accidents including storms and typhoons. Negligence of the master and crew was also covered. Clause 3 provided that in no case would the insurance cover loss, damage, liability or expense caused by the unseaworthiness of the insured vessels and negligence of the shipowner. During the insurance period, the insured vessels navigated with insufficient crew and were hit by storms and a typhoon. The crew was negligent in the management of the vessels during the typhoon and storms. This ultimately resulted in the vessels being stranded and lost.

It was found that the concurrent proximate causes of the loss were the typhoon, the shipowner's negligence and the crew's negligence in the management of the vessels. ${ }^{80}$ According to the insurance contract, the typhoon and the crew's negligence were covered risks but the shipowner's negligence was an excluded risk of the insurance. This situation seems similar to that of The Hong $\mathrm{Da} 158$. However, under the Chinese Insurance Law, for those clauses that exempt the insurer from liability in the insurance contract, the insurer must point out those clauses to the policy holder in the insurance application form, the insurance policy or any other insurance certificate, and expressly explain the contents of those clauses to the policy holder in writing or orally; if the insurer fails to warn about them or give an explicit explanation thereof, those clauses shall not be effective. ${ }^{81}$ It was found that the insurer did not explain the exclusions in Clause 3 of the insurance to the insured when the contract was concluded. By failing to do so, this made Clause 3 null and void according to the Chinese Insurance Law. The excluded risks in Clause 3 ceased to be expressed risks in the insurance and became uninsured risks according to the classification of risks. Therefore, the issue in The Lu Rong Yu 1813 \& The Lu Rong Yu 1814 was the insurer's liability for the loss concurrently caused by the insured perils and uninsured perils. The circumstances are similar to those of The Miss Jay Jay. ${ }^{82}$ However, unlike the English courts in The Miss Jay Jay, the SPC took into account the uninsured peril for the insurer's liability. It believed that the typhoon as the insured peril had a direct and significant potency on the

\footnotetext{
${ }^{79}$ (2012) QHFHSCZ No 240 (Qingdao Maritime Court, First Instance); (2016) LMZ 1542 (Shandong High People's Court, Second Instance); (2017) ZGFMZ 413 (SPC, Retrial); reported in [2019] 3 Chinese Maritime and Commercial Law Reports (CMCLR) 10.

${ }^{80}$ Ibid, at 15 .

${ }^{81}$ Chinese Insurance Law, art 17, para 2.

${ }^{82}$ [1987] 1 Lloyd's Rep 32.
} 
loss of the vessels, and the negligence of the shipowner and the crew as uninsured perils only had a certain amount of potency. Therefore, the typhoon was the main proximate cause of the loss and the insurer was held liable for $75 \%$ of the loss. ${ }^{83}$

The SPC judges in The Lu Rong Yu 1813 \& The Lu Rong Yu 1814 described the excluded risks as uninsured risks. The excluded risks are substantially different from uninsured risks for the insurer's liability under English law. They are, however, the same under Chinese judicial practice because the insurer is liable for the loss in apportionment where one of the proximate causes is an insured risk, no matter that the other concurrent causes are excluded risks or uninsured risks, because the insurer is not liable for the loss due to those causes. However, it is argued that uninsured risks should be different from excluded risks. Under the exclusion clause, the liability for loss caused by excluded risks has been contractually excluded. That is an express intention of the parties to the insurance contract. The uninsured risks, however, are the risks that are not insured or excluded. They could be the proximate causes to the loss of the subject matter insured as a matter of fact, but they are not expressed risks in the insurance contract as a binding agreement between the parties. The reason those risks are called uninsured risks is not for inclusion or exclusion of the insurer's liability, but for the purpose of describing a matter of fact: they are just not expressed in the insurance contract. Therefore, an uninsured risk does not affect the insurer's liability and should not be an excuse to exempt the insurer's liability under concurrent causation. Otherwise, uninsured risks will become an excuse for the apportionment of liability between the insurer and the insured. This is obviously against the intention of the parties to the insurance contract, because the uninsured peril was not mentioned at all. The contrasting rationale in The Miss Jay Jay seems more reasonable and acceptable.

\section{Concurrent causation and proximate cause}

\section{(a) Sole proximate cause}

It is accepted that the proximate cause does not have to be the sole cause. ${ }^{84}$ However, there are few reported cases in which two causes have been identified as the concurrent proximate causes. Although the reasoning of the Court of Appeal in Wayne Tank has been treated in subsequent cases as having settled the question under discussion, only one cause was actually identified as the sole proximate cause. In Wayne Tank, the insured, who carried on business as engineers and installers of storage devices for industrial fluids, effected a public liability insurance policy. The insured installed some storage tanks at a plasticine mill. A disastrous fire occurred at the mill. The insurer had to pay damages and claimed an indemnity from the insurer under the policy. As a matter of fact, there were two causes of the disaster. The first cause was the dangerous nature of the installation which was plainly within an exception clause of the policy. Taking that clause alone, the insurance company would be exempt by reason of the exception clause. The second cause was the conduct of the man in switching on the heating tank and leaving it unattended all night, which was not within the exception clause. Taking that cause alone, the insurance company would be liable under the general words. ${ }^{85}$ On the question of what the effective or dominant cause of the fire was, Lord Denning MR answered that, as a matter of common sense, it was the dangerous installation of a pipe which was likely to melt under heat. As for the misconduct of the man in switching on the heating tank, he took the view that it was 'just the trigger - the precipitating event - which brought about the disaster'. ${ }^{86}$ Accordingly, the exception clause could be relied on by the insurer. Lord Denning MR did not explain whether it was also a matter of common sense that the misconduct of the man was just a trigger if the other concurrent cause was considered as the proximate cause. Finding one

\footnotetext{
${ }^{83}$ [2019] 3 CMCLR 10, at 18.

${ }^{84} \mathrm{~J}$ Mance et al Insurance Disputes (London: Informa, 3rd edn, 2011) para 7.15. See also F Rose Marine Insurance: Law and Practice (London: Informa, 2nd edn, 2012) paras 19.23-19.24.

${ }^{85}$ Wayne Tank, above n 5 , at 829.

${ }^{86}$ Ibid, at 830 .
} 
proximate cause from concurrent causes can avoid the complex tangle of concurrent causation. As Lord Denning MR said in Wayne Tank, 'that is enough to decide the case'. ${ }^{87}$

It is submitted that the Wayne Tank rule is unlikely to be engaged by the standard exclusions in the Institute Cargo Clauses with regard to ordinary leakage, ordinary loss in weight or volume and ordinary wear and tear (clause 4.2) and inherent vice (clause 4.4). These exclusions substantially mirror the limitations set out in section 55(2)(c) of the Marine Insurance Act $1906 .{ }^{88}$ Section 55(2)(c) provides that, unless the policy provides otherwise, the insurer is not liable for ordinary wear and tear, ordinary leakage and breakage, or the inherent vice or nature of the subject matter insured. The insurer is not liable for such risks because they are not fortuitous accidents or casualties, but the inevitable nature or result of the subject matter insured. Such risks, eg inherent vice, may have a potency on the subject matter insured along with external events which concurrently cause loss of or damage to the subject matter insured. They are, however, not recognised as concurrent causes at common law. In Soya $G m b H v$ White, ${ }^{89}$ Lord Keith interpreted inherent vice to mean the risk of deterioration of the goods shipped as a result of their natural behaviour in the ordinary course of the contemplated voyage without the intervention of any fortuitous external accident or casualty'. ${ }^{90}$ This interpretation was cited in The Cendor Mopu. ${ }^{91}$ Lord Clarke pointed out that Lord Keith defined 'inherent vice' in opposition to perils of the seas, thereby avoiding any overlap between the insured risk and the excluded risk. Thus, Lord Clarke believed that where 'a proximate cause of the loss was perils of the seas, there was no room for the conclusion that the loss was caused by inherent vice'. ${ }^{92}$ It is therefore submitted that, if there is a loss which is the result of perils of the seas, the assured is entitled to recover even though the insurer can show that the loss was contributed to by non-maritime perils, eg inherent vice affecting the subject matter insured. Thus, it is doubted whether The Miss Jay Jay would still be good law as to concurrent causes. It is believed that The Cendor Mopu may be deemed as authority to reject concurrency between internal risks and external ones. ${ }^{93}$

It must be noted that the relationship between the insured risk and the excluded risk in both the statutory rules and common law is an interdependent one. This means that one risk will not cause the loss 'but for' the other risk. For example, in The Cendor Mopu, the loss resulted from metal fatigue in the three legs of the oil rig, which was the subject matter insured, in the form of progressive cracking resulting from repeated or fluctuating stresses each at a level lower than that required to cause the fracture of an uncracked component. The stresses were generated from the effect that the height and direction of the waves had on the pitching and rolling motion of the barge, and thus on the legs. As a matter of fact, the metal fatigue and the leg-breaking waves were interdependently concurrent causes, although, as a matter of law, it was only the leg-breaking wave that was considered the sole proximate cause by applying the definition of inherent vice. The interdependent relationship provides the possibility to identify a sole proximate cause by finding another cause as a trigger event or defining concepts of non-maritime perils, eg inherent vice. However, the concurrent causes may be independent. For example, in Kastor Navigation Co Ltd v Axa Global Risks (UK) Ltd, ${ }^{94}$ a shipowner claimed to recover for constructive total loss of a vessel caused by an engine room fire where the vessel afterwards

\footnotetext{
${ }^{87}$ Wayne Tank, above n 5, at 830. However, Lord Denning MR continued to discuss the circumstance if the two causes were equal or nearly equal in their efficiency in bringing about the damage, namely the concurrent causation for the argument of this issue.

${ }^{88}$ Gilman, above n 2, paras 22-32.

${ }^{89}$ [1983] Com LR 46.

${ }^{90} \mathrm{Ibid}$, at 126 .

${ }^{91}$ [2011] UKSC 5, [2011] 1 All ER 869.

${ }^{92}$ Ibid, at [111]. See also Ace European Group Ltd $v$ Chartis Insurance UK Ltd [2013] EWCA Civ 224.

${ }^{93}$ Song, above n 6, p 56.

${ }^{94}$ [2004] EWCA Civ 277, [2005] 2 All ER (Comm) 720. See also, in Tektrol Ltd $v$ International Insurance Co of Hanover Ltd [2005] EWCA Civ 845, [2006] 1 All ER (Comm) 780, the assured's business was based on a computer source code. A computer virus had erased copies of the code from the laptop and the remote site and afterwards the assured's premises had been burgled and the two computers and hard copy of the source code had been stolen. All copies of the source code had been lost and the insured sought to recover under the policy.
} 
sank and was an actual total loss as a result of the ingress of seawater from a different and unexplained cause. The Court of Appeal held that it was open to the judge to conclude that the fire was an independent cause of loss from the ingress of water.

If a loss is caused by two independently concurrent causes, it is hard to find one proximate cause between the excluded risk and the insured risk because each risk may cause the loss independently. ${ }^{95}$ It is argued that the 'but for' test in the interdependent relation is a necessary but not sufficient test to ascertain a proximate cause, which means the proximate cause should still meet with the test primarily, as one of the necessary conditions of the loss. Therefore, in order to constitute a concurrent proximate cause, each peril must also be a necessary condition to the loss as an independent cause. ${ }^{96}$ In Financial Conduct Authority v Arch Insurance (UK) Ltd and Others, ${ }^{97}$ the Supreme Court held that the 'but for' test of causation is sometimes inadequate and that there can be situations where a series of events all cause a result although none of them was individually either necessary or sufficient to cause the result by itself. Hence, it may not be appropriate to identify only one proximate cause from more than one independently concurrent cause. In this circumstance, the apportionable liability approach might be considered a solution to the question of the insurer's liability under concurrent causation.

\section{(b) Liability in apportionment in insurance}

In The Lu Rong Yu 1813 \& The Lu Rong Yu 1814, the SPC for the first time summarised the general rules for determining the insurer's liability in non-life insurance. The SPC pointed out that determination of the insurer's liability mainly involves identification of the causes of the accident, the scope of the insurance coverage, exclusions of insurance liability and the degree of potency from insured risks. As to whether an insurer shall be liable for a loss and the extent of liability, if any, it is first necessary to examine whether the proximate causes are covered risks of the insurance, and then whether the exclusions of liability are valid and the insurer is therefore exempted from liability based on contractual or statutory exclusions. Lastly, the extent of liability shall be determined according to the degree of potency from the insured risks. ${ }^{98}$ The last rule established the apportionable liability approach in nonlife insurance under concurrent causation in Chinese judicial practice. ${ }^{99}$ This means that the insurer bears the liability of indemnity in apportionment if one of the concurrent causes is an insured risk, no matter whether the other cause is an excluded risk ${ }^{100}$ or an uninsured risk. ${ }^{101}$

Two questions on the apportionable liability rule are still outstanding. First, what is the relationship between the insured risk and the excluded risk in concurrent causation? If the insurer's liability for the loss caused by insured risks is subject to or excluded by the excluded risks, the excluded risks should prevail over the insured risks. However, the SPC did not explain which risk prevails over the other. If the insured risk prevails, the insurer should be liable for the loss concurrently caused by both causes. In contrast, the insurer should not be liable if the excluded risk prevails. Apportionable liability seems reasonable only if there is no priority between the insured risk and the excluded risk. Therefore, there should be a third rule between the second rule and the last rule in the SPC's interpretation in The $L u$ Rong Yu 1813 \& The Lu Rong Yu 1814. The third rule should examine the intention of parties

\footnotetext{
${ }^{95}$ In McCarthy v St Paul International Insurance Co Ltd [2007] FCAFC 28, Kiefel J of the Full Court of the Federal Court of Australia was of the view that the issue was one for the construction of the policy and the existence of two causes, one of which was excluded, was not fatal to a claim.

${ }^{96}$ Song, above n 6, p 62.

${ }^{97}$ [2021] UKSC 1.

${ }^{98}$ [2019] 3 CMCLR 16.

${ }^{99}$ China does not have the precedent rule and therefore judgments are not a source of law in China. However, judgments from superior courts, in particular the appellate courts and the SPC are persuasive and considered in the judicial practice of Chinese courts.

${ }^{100}$ The Hong Da 158, above n 66.

${ }^{101}$ The Lu Rong Yu 1813 \& The Lu Rong Yu 1814, above n 79.
} 
regarding the insurer's liability for a loss caused concurrently by insured risks and excluded risks by interpreting the insurance contract. If no intention can be found, the apportionable liability approach in the last rule may apply as a final solution to the question of the insurer's liability under concurrent causation. In this circumstance, apportionable liability seems better than the all or nothing approach under English common law. ${ }^{102}$ Secondly, since the uninsured risk is not mentioned, why should the uninsured risk be considered for the apportionable liability of the insurer under the last rule? It is reasonable not to mention it in the second rule if the uninsured risk is not mentioned in the insurance contract, namely that it is not insured or excluded. It is therefore reasonable not to consider an uninsured risk if a loss was concurrently caused by the uninsured risk and an insured risk. It is submitted that the apportionable liability approach should not apply to concurrent causation where one of the causes is an uninsured risk.

\section{(c) Liability in apportionment in contract and tort}

Concurrent causation is an issue not only in insurance law, but also in contract and tort law of English law. In Heskell $v$ Continental Express $L t d,{ }^{103}$ it was held that if a breach of contract is one of two causes, both co-operating and both of equal efficacy, ... it is sufficient to carry judgment for damages' ${ }^{104}$ In Smith Hogg \& Co Ltd $v$ Black Sea \& Baltic Insurance Ltd, ${ }^{105}$ the concurrent causes included the serious overloading of a vessel, a breach of contract for which the shipowners were responsible, and incompetent refuelling for which they were not responsible under the contract of carriage, to capsize her and cause the loss of the cargo. It was held that the shipowners were liable for the loss of cargo and it was immaterial that other causes from whose effect the shipowner was excused contributed to occasion the loss. An insurance contract is a commercial contract, but it has special characters compared to a general commercial contract. The distinction between them is the exclusions in insurance contracts. It is immaterial in a general contract that other causes from whose effect the wrongful party is excused have contributed to a loss concurrently caused by a breach of contract. It is, however, material in an insurance contract that the insurer can exclude its liability even if the other concurrent cause is a covered risk. ${ }^{106}$ Ignoring the exclusions in an insurance contract is against the intention of the parties to that contract. ${ }^{107}$ Therefore, the concurrent causation rule of contract law is not appropriate to be adopted by insurance law.

Where a loss is the result partly of a party's breach of contract and partly of some act of the counterparty, the parties' liability may be apportioned. In Tennant Radiant Heat Ltd $v$ Warrington Development Corpn, ${ }^{108}$ a flood damaged the landlord's and tenant's parts of an industrial unit owing to an ingress of water caused by breaches by both parties of their mutual repair obligations. The tenant was in breach of an express repairing covenant in respect of their failure to maintain to the unit. The landlord was, however, liable in nuisance and negligence for their failure to maintain the unit. The liability for the overall damage was apportioned by the Court of Appeal according to the causative potency of each breach. However, the validity of this holding in the Tennant case was doubted. ${ }^{109}$ It is believed that it is very hard to reconcile with a subsequent decision of the Court of Appeal that default of the claimant cannot affect contract damages outside the purview of the

\footnotetext{
${ }^{102}$ Wayne Tank, above n 5.

${ }^{103}$ [1950] 1 All ER 1033.

${ }^{104} \mathrm{Ibid}$, at 1048 .

${ }^{105}[1940] 3$ All ER 405.

${ }^{106}$ Wayne Tank, above n 5.

${ }^{107} \mathrm{Eg}$, in Institute Cargo Clauses (A), clause 1 provides that 'This insurance covers all risks of loss of or damage to the subject-matter insured except as excluded by the provisions of Clauses 4, 5, 6 and 7 below'.

${ }^{108}$ [1988] 1 WLUK 534.

${ }^{109} \mathrm{~N}$ Andrews et al Contractual Duties: Performance, Breach, Termination and Remedies (London: Sweet \& Maxwell, 3rd edn, 2020) para 24-030.
} 
Law Reform (Contributory Negligence) Act $1945 .{ }^{110}$ The precedential value of the Tennant case was treated as confined to its own facts. ${ }^{111}$ A special fact in the Tennant case was that the action included claim and counterclaim. Therefore, the liability approach under concurrent causes in contract law could not be simply applied. The apportionable liability in the Tennant case seems similar to the circumstance of apportionable liability in tort law, although the Law Reform (Contributory Negligence) Act 1945 did not apply in the Tennant case. ${ }^{112}$

The English law of tort has always been prepared to accept that one event can have two or more concurrent causes. ${ }^{113}$ In tort law, a defence is available where it is proved that the claimant's own negligence contributed to its loss or damage. The Law Reform (Contributory Negligence) Act 1945 permits apportionment of loss where the fault of both claimant and defendant have contributed to the damage. ${ }^{114}$ A claim for damages will be reduced by such extent as the court thinks 'just and equitable' having regard to the claimant's share in responsibility for the damage. ${ }^{115}$ The Act was designed for the tort of negligence, ${ }^{116}$ but can be applied to cases of contractual breaches where the defendant's liability in contract is the same as his liability in negligence. ${ }^{117}$ Insurance law is also different from tort law in terms of concurrent causation. Both covers and exclusions are intentions of parties in insurance, but there are no contractual exclusions for liability in tort. A fault of one party can reduce the counterparty's liability in tort, whereas an exclusion can exclude the insurer's whole liability under insurance. Therefore, although the adoption of the apportionable liability approach is suggested for independent concurrent causation if there is no relevant contractual intention on it, the rationale of the suggestion is different from that of tort law.

\section{Conclusion}

Neither the priority of the exclusion approach nor the apportionable liability approach is a flawless means of determining the insurer's liability under concurrent causation in insurance. The solutions are summarised as follows. First, the insurer's liability should be determined according to the intention of parties by interpreting the insurance contract clauses. Well-drafted contract clauses may solve the problem of the insurer's liability under concurrent causation. For example, it is agreed that a risk is covered only if it is the sole and direct cause of the loss, ${ }^{118}$ or an insurer may exclude its liability for a loss if it is in any way caused or contributed to by an excluded peril. ${ }^{119}$ Giving priority to any one of the concurrent causes should be avoided if there is no express clause for such priority. Secondly, if no intention can be identified by construction of the contract, concurrent causation can be decided in two circumstances: (i) where an insured risk and an excluded risk are interdependent and concurrently cause the same loss, a sole proximate cause should be identified so as to avoid the existence of concurrent causation; (ii) where those risks are independently concurrent, the liability in apportionment approach under the principle of 'balance of interests' is proposed, to replace the Wayne

\footnotetext{
${ }^{110}$ Barclays Bank plc v Fairclough Building Ltd [1995] 1 All ER 289.

${ }^{111}$ Hi-Lite Electrical Ltd $v$ Wolseley UK Ltd [2011] EWHC 2153 (TCC).

${ }^{112}$ The Law Reform (Contributory Negligence) Act 1945 was not applicable because the tenant's breach of covenant was not tortious.

${ }^{113}$ Stapley $v$ Gypsum Mines Ltd [1953] 2 All ER 478.

${ }^{114}$ Before the Act was passed, English tort law had held that contributory negligence was a full defence to negligence. This is a harsh common law defence.

${ }^{115}$ Law Reform (Contributory Negligence) Act 1945, s 1(1).

${ }^{116}$ The concept of 'fault' in the Act means negligence, breach of statutory duty or other act or omission which gives rise to a liability in tort or would, apart from this Act, give rise to the defence of contributory negligence: Law Reform (Contributory Negligence) Act 1945, s 4.

${ }^{117}$ Forsikringsaktieselskapet Vesta $v$ Butcher [1988] 2 All ER 43 (in the decision of the House of Lords [1989] 1 All ER 402, contributory negligence was not dealt with).

${ }^{118}$ Merchants' Marine Insurance Co Ltd v Liverpool Marine and General Insurance Co Ltd [1928] All ER Rep 452.

${ }^{119}$ Coxe v Employers' Liability Insurance Corpn [1916] 2 KB 629; American Tobacco Co v Guardian Assurance Co (1925) 22 Ll LR 37.
} 
Tank rule. Lastly, uninsured risk is not a real risk in an insurance contract but more of a concept in the theory of insurance law. It could be ignored in determining the insurer's liability if the other concurrent causes are insured risks or excluded risks. The apportionable liability approach is not appropriate for such concurrent causation.

Cite this article: Zhao L (2022). Insurer's liability under concurrent causation: English law and Chinese law compared. Legal Studies 42, 120-136. https://doi.org/10.1017/lst.2021.31 